\title{
IMPACT OF SARBANES-OXLEY AND IRS FORM 990 ON NONPROFIT ORGANIZATIONS IN PENNSYLVANIA
}

\author{
Matthew R. Kisow, D. Sc., NSABP Foundation, Inc., matt.kisow@nsabp.org
}

\begin{abstract}
The Sarbanes-Oxley act attempted to reform public sector organizations that suffered from a series of scandalous failures in the late 1990's; this legislation however, did not apply to the nonprofit sector. Following several highprofile scandals, surrounding nonprofit sector organizations between 1996 and 2002, congressional lawmakers led an unsuccessful attempt to extend the Sarbanes-Oxley act to the nonprofit sector. Using the regulatory power of the IRS (Internal Revenue Service) a redesigned Form 990, “Return of Organization Exempt from Income Tax," has emerged as a means to enhance the transparency and accountability of nonprofit sector organizations.
\end{abstract}

Based upon the principles of the Sarbanes-Oxley act the revised Form 990 is, perhaps too onerous and expensive for small and midsized nonprofit organizations to implement due to the low reporting thresholds of this new regulation. Anecdotal evidence indicates that such a low reporting threshold negatively impacts small and midsized nonprofit organizations.

The research carried out in this study sought to discover what impact the revised IRS Form 990 has had on nonprofit governance, the degree to which the nonprofit sector has adopted these control mechanisms outlined in this revised regulation and the application of these "best practices" for effective decision making policies.

Keywords: Sarbanes-Oxley Act, IRS Form 990, nonprofit sector, business, best practices

\section{INTRODUCTION}

The Sarbanes-Oxley Act of 2002 is federal legislation that was implemented to curtail incidents of fraud and abuse that led to the collapse of, among others, Enron, WorldCom, and Arthur Anderson. The failures of these organizations came at a great financial and human cost [2, 5, 17]. This act enhanced corporate accountability, responsibility, and financial reporting transparency among publicly traded companies. Requirements such as certification of financial reports by an organization's top officer and a greater emphasis on internal controls, and independent audit committees [12] have placed greater demands on executives and other internal resources while changing the roles and relationships of the board of directors, audit committees, auditors, and management [12].

Most provisions of the Sarbanes-Oxley act apply only to publicly traded companies; however, several states are considering similar regulation for nonprofit organizations [10] for example the state of California passed the California Nonprofit Integrity Act of 2004 [21], which provides for accountability and governance measures similar to those of Sarbanes-Oxley for nonprofits in that state. Furthermore, the Panel on the Nonprofit Sector a leading nonprofit trade organization recommended more than 120 actions be taken by nonprofit organizations, Congress, and the Internal Revenue Service to strengthen the nonprofit sector's transparency, governance, and accountability $[12]$.

Sarbanes-Oxley measures such as section 404 establish requirements on internal controls that have proven to be extraordinarily expensive for organizations to implement $[4,16]$. These controls may require information technology and accounting professionals, from both inside and outside organizations, to provide services as the organizations attempt to comply with the internal control standards of the act [18], such services have proven to be very expensive $[4,16]$.

Any proposed legislation at the state level is likely to emulate the governance mechanisms that are available in the Sarbanes-Oxley Act. The California Nonprofit Integrity Act of 2004 [12, 21], for example, copies these provisions. This law requires California nonprofit organizations to: 1) incorporate the expansion of whistleblower protection; 2) require the organization's top officer to sign the annual financial statements; 3) require an organization to appoints an audit committee; and 4) increase the criminal penalties against those who commit fraud. New Hampshire, 


\section{Issues in Information Systems}

Volume 15, Issue I, pp. 61-70, 2014

Massachusetts, Connecticut, and Kansas currently require nonprofit organizations with annual revenue greater than $\$ 1$ million to have audited financial statements. Nonprofit organizations may wish to adopt these provisions voluntarily to comply with the provisions of Sarbanes-Oxley in an effort to preclude future onerous legislation [12].

According to Fremont-Smith \& Kosaras [5], the prevalence of unethical behavior in the nonprofit sector mirrors that in the public sector. According to this study during the seven years prior to Sarbanes-Oxley being signed into law in 2002, officers and directors of 152 major charitable organizations defrauded donors of at least $\$ 1.1$ billion. Their study further indicated that the fraud and abuse by these officers and directors could in fact be far worse, as this study based the 1.1 billion amount on surveys of newspaper reports, which may have significantly underestimated the abuses within the nonprofit community [5]. Adelphi University, Allegheny Health, Education Research Foundation, the United Way, the International Olympic Committee and its Utah affiliate, the New Era Philanthropy, and the NAACP are organizations that have experienced incidents of financial fraud and abuse [6, 12]. Experiencing pressure from contributors, legislators, regulators, bond underwriters, and liability insurers, nonprofit organizations are becoming more accountable by adopting Sarbanes-Oxley compliance into their governance [12, 15]. Because much of a charity's funding comes from donors, it is important for nonprofit organizations to maintain the public's trust. The Independent Sector, a leading nonprofit trade organization, "recommend[s] that all nonprofits voluntarily incorporate certain provisions of the [Sarbanes-Oxley] Act that make good governance sense" [20].

Some aspects of the Sarbanes-Oxley Act already apply to nonprofit organizations, such as the establishment of whistleblower protections and document retention policies [8, 11, 12, 23]. Further more, beginning in the 2009 tax year, a revised Form 990 designed to enhance the transparency and accountability of the nonprofit sector has been put in place by the IRS to further enhance the nonprofit sector's governance [22, 24]. Orlikoff \& Totten [15] point out that underwriters and liability insurers now require nonprofit organizations to voluntarily provide these measures in their governance.

\section{Problem Statement}

The requirements of the IRS Form 990 are effective for nonprofit transparency and accountability, but are perhaps too expensive for small and midsized nonprofit organizations. Complicating this issue is the low threshold of IRS mandated reporting. Anecdotal evidence indicates that such a low reporting threshold negatively impacts midsized nonprofit organizations.

\section{Purpose of Study}

The purpose of this research study is to provide insight into how Pennsylvania nonprofit organizations are changing their governance to comply with IRS Form 990, and to evaluate whether they are adopting governance measures from the Sarbanes-Oxley Act. Specifically, the researcher has investigated whether larger nonprofit organizations in Pennsylvania are more likely to voluntarily adopt these provisions into their governance over their smaller counterparts.

\section{Research Question}

This research study will examine the degree to which Pennsylvania nonprofit organizations have voluntarily changed their governance mechanisms to comply with the revised IRS Form 990 and to what degree they are adopting Sarbanes-Oxley regulations into their governance. Specifically, this research study will be conducted to examine the following research questions:

1) Are Pennsylvania nonprofit organizations familiar with the IRS Form 990 changes and the governance mechanisms available in the Sarbanes-Oxley Act?

2) Has the redesigned Form 990 caused Pennsylvania nonprofit organizations to adopt aspects of the Sarbanes-Oxley Act into their governance?

3) Are Pennsylvania nonprofit organizations audit committees and boards of directors established to ensure independence and knowledge of finance or financial auditing? 
4) Are Pennsylvania nonprofit organizations familiar with the updated whistleblower provisions of the Sarbanes-Oxley Act?

5) Are Pennsylvania nonprofit organizations' top officers certifying financial reports and implementing a control structure conducive to preventing incidents of unethical abuses, malfeasance, and financial irregularities?

\section{Previous Research}

This study is based on a study conducted by Iyer \& Watkins, "Adoption of Sarbanes-Oxley Measures by Nonprofit Organizations: An Empirical Study" [12], which was conducted by surveying 600 South Carolina nonprofit organizations. The Iyer \& Watkins survey instrument has been employed in part to answer the above research questions. Additionally questions have been added and modified to address the impact that the revised IRS Form 990 has had on Pennsylvania nonprofit organizations.

\section{Limitations}

This research study is limited in scope by the data collection instrument and the demographics of the study's sample population. The data for this study were captured using an instrument that had been used in a previous research study addressing the adoption of Sarbanes-Oxley governance measures by nonprofit organizations. This instrument was adapted for the current research to address the adoption of Sarbanes-Oxley governance measures as a result of the revised IRS Form 990. Changes in the revised version were minor in scope and are explained in the methodology section of this research project. The sample for this project was derived using a simple random sampling technique. Although every effort was made to ensure a representative sample of Pennsylvania nonprofit organizations, there is a 2:1 ratio of large vs. small organizations represented among those who replied. These limitations placed constraints on the generalizability of the collected data. Therefore, every effort has been made to ensure that the conclusions drawn are representative of the population.

\section{REVIEW OF THE LITERATURE}

\section{Introduction}

A review of the literature addressing the nonprofit sector's accountability and transparency over the past 12 years discloses that accusations of fraud and abuse have eroded the public's trust of nonprofit organizations. In an effort to increase transparency and accountability of these organizations the IRS has for the first time since 1979 revised Form 990.

\section{An Erosion of Public Trust}

In a 2003 working paper by Fremont-Smith \& Kosaras [5], "Wrongdoing by Officers and Directors of Charities: A Survey of Press Reports 1995-2002," newspaper reports from across the United States were researched and surveyed, the authors estimated that officers and directors of nonprofit organizations had defrauded donors out of $\$ 1.1$ billion in 152 separate incidents over a seven-year span of time. The Allegheny Health, Education and Research Foundation [5, 12], The United Way [5, 7] and Adelphia University were among those identified. It was concluded by Fremont-Smith \& Kosaras [5] that this situation may in fact be much worse, creating an impression that there may be serious under-reporting. The study went on to note that there was a wide discrepancy in the severity of prosecutions and sentencing in such cases.

Accusations of fraud and abuse have damaged nonprofit organizations. A nonprofit organization's ability to conduct fund raising efforts, for example, can be hindered by reports of misconduct and malfeasance [5]. Overall, reports of wrongdoing have impacted the long-term sustainability of nonprofit organizations in which public trust is a principal commodity. 


\section{Independent Audits}

All nonprofit organizations utilizing independent auditors should have independent audit committees. Independent audit committees of nonprofit organizations made up of independent members of the board of directors and the disclosure of at least one of these members as a financial expert is a requirement of section 407 of the SarbanesOxley Act $[12,17]$. This requirement exists so that the board of directors understands the financial statements and has the wherewithal to retain and supervise the external auditors $[1,12,17,19]$.

\section{Whistleblower Protection}

The whistleblower protections of Sarbanes-Oxley apply to both the public and nonprofit sectors. This provision protects employees by granting special damages and attorney's fees and prohibits employers from taking certain actions against workers who lawfully disclose information regarding a crime $[1,12,17]$. Sarbanes-Oxley also provides for criminal penalties for actions taken against whistleblowers.

\section{Financial Controls}

It is the responsibility of the nonprofit organization's top officer to understand the financial statements to ensure that they fairly represent the organization's activities. The responsibility for approving the reports, however, lies with the board of directors $[12,19]$.

Sarbanes-Oxley emphasizes internal financial controls in section 404 and requires these disclosures in the annual report. This report should: 1) state the responsibility of the organization's top officer for establishing and maintaining an internal control structure for financial reporting, and 2) contain an assessment of the effectiveness of the internal control structure. Further, this report should contain an evaluation of the organization's controls attested to by the organization's independent auditor to ensure accurate reporting $[12,14,17]$.

\section{IRS Revisions to Form 990}

For the first time since 1979 The Federal Government has revised its IRS Form 990 to enhance the governance, transparency, and accountability of nonprofit organizations [1, 3, 9, 22]. Starting in the 2008 tax year, the redesigned 990 is meant to bridge the gaps in the previous 990 that had failed to meet the IRS's tax compliance interests and the transparency and accountability needs of the state and federal government [3, 22]. This revised form is meant to minimize the burden of filing on nonprofit organizations as well as to promote tax compliance [9, 22]. The increased disclosure to the IRS and, inevitably, the scrutiny of donors to these organizations has incorporated the principles and best practices introduced by the Sarbanes-Oxley Act [1, 3, 22].

These new requirements apply to all nonprofit organizations, which must now annually file a Form 990, and lower the thresholds at which nonprofit organizations must file from $\$ 2.5$ million to $\$ 500,000$ beginning in the 2010 tax year $[1,3,22]$. These changes seem to underscore the belief that the best practices developed under Sarbanes-Oxley and California's Nonprofit Integrity Act are no less relevant to nonprofit organizations [13, 17, 21, 22].

The relevance of transparency and accountability in nonprofit governance is clear. According to Bakale [1], there is concern among top officials of the federal government about issues of transparency among nonprofit organizations. Perhaps one of the core issues is poor governance. This issue has time and time again not kept up with modern practices and must be addressed [1,22]

\section{METHODOLOGY}

\section{Introduction}

The purpose of this research study is to learn whether Pennsylvania nonprofit organizations are changing their governance to comply with IRS Form 990, and to describe whether they are adopting the governance measures from the Sarbanes-Oxley Act. Specifically, I investigated whether larger nonprofit organizations in Pennsylvania were 


\section{Issues in Information Systems}

Volume 15, Issue I, pp. 61-70, 2014

more likely to voluntarily adopt these provisions into their governance processes than their smaller counterparts.

\section{Participants}

The participants were all 501(c)(3) non-profit organizations that file IRS Form 990 in Pennsylvania. To obtain this sampling frame I requested a list of all 501(c)(3) nonprofit organizations from Pennsylvania's Department of State. This electronic list contained the names, addresses and phone numbers of the organizations' contacts. The sampling procedure was performed by randomly sorting the electronic list in a spreadsheet then selecting the first $632(10 \%)$ organizations. By choosing $10 \%$ the sampling margin of error was less than .01\%. E-mail addresses were added to each of these 632 records by searching the Internet for the organization's name and address. In the event an organization did not have electronic contact information available on the Internet, phone calls were made to request their participation. Of the 632 organizations contacted, 170 (27\%) were eliminated for the following reasons: 1) 97 $(15 \%)$ did not return the researcher's request for contact either by e-mail or phone call; 2$) 35$ (5\%) requested not to be included in the study; 3$) 34$ (5\%) expressed concerns over the confidentiality of the survey; and 4) 4 (2\%) no longer exist or had become for-profit entities.

Responses were received from 153 organizations. By budget size there were 62 organizations of $\$ 0-\$ 500,000$ and 91 organizations of $\$ 501,000->\$ 1,000,000$ by number of employees, there were 121 organizations with less than 100 employees and 32 organizations with greater than 100 employees. The individuals who responded were: Executive Directors (58), CEO (37), Vice President (17), Controller (14), Board Member (15) and 12 in the other category.

\section{Survey Instrument}

Iyer and Watkins [12] conducted a similar study in North Carolina using their own instrument that contained 31 questions. Because the instrument contained the kinds of questions suitable for answering my research questions, I adapted it, using 24 of their questions. The remaining 6 questions were removed from the survey because they did not pertain to my research.

This updated instrument contained 24 questions on six topics: demographics, awareness of Sarbanes-Oxley, audit committee and board of directors, whistleblower protections, certification of financial information, and internal accounting and information technology controls.

\section{Data Collection Procedures}

Data collection occurred between June 2010 and July 27, 2010. The researcher sent 462 e-mails that contained a hyper-link to the surveys. The e-mails were sent to the attention of the executive directors, CEO, Vice President, Controller or Board Members of the respective organizations. The email contained an introduction, explaining who I was and what information the study intended to collect and the hyperlink to the survey. Reminder notices were sent bi-weekly with a final notice sent July 27, 2010. A total of 153 organizations completed the survey for a $33 \%$ response rate.

\section{ANALYSIS OF DATA}

\section{Introduction}

The data used in this research study were collected using an electronic survey tool, rmu.vovici.net. The survey was modified by the researcher to determine what impact, if any, the revised IRS Form 990 had on Pennsylvania nonprofit organizations' adaption of Sarbanes-Oxley governance mechanisms into their governance. The survey was adapted from the Iyer \& Watkins [12] study. On June 28, 2010, The Vovici tool was scheduled to send out 531 electronic surveys. Reminder notices were sent bi-weekly with a final notice sent July 27, 2010. During this time 35 organizations requested removal. These requests fell into the following two categories: 1) the organizations representative felt they did not have time to complete the survey and 2) the organization's representative felt the email soliciting a response for the studies research was spam and subsequently requested removal. An additional 34 


\section{Issues in Information Systems \\ Volume 15, Issue I, pp. 61-70, 2014}

organizations representatives requested removal for confidentiality concerns. The actual population for this research study was 462 organizations, making the margin of error for this sample plus or minus $\sqrt{ }(.50(1-.50) / 462) * 1.96=$ $4.56 \%$ A total 153 organizations completed the survey giving the researcher a $33.12 \%$ rate of return.

\section{Survey Results}

After dichotomizing the data in question 3 into organizations with an annual budget less than or equal to $\$ 500,000$ and those with a budget greater than $\$ 500,000$ the researcher found that there were 62 and 91 organizations, respectively. After dichotomizing the data from question 4 into organizations with 100 or fewer employees and those with more than 100 employees, the researcher found that there were 121 and 32 organizations, respectively. When these two new dichotomized variables were cross-classified, all 62 organization with a annual budget of $\$ 500,000$ or less were shown to have 100 or fewer employees (Small / Few), and of those with an annual budget of more than $\$ 500,000,59$ had 100 or fewer employees (Large / Few) and 32 had more than 100 employees (Large / Many). Therefore, there were three types of organizations: 1) those with a small budget and few employees (62);2) those with a large budget and few employees (59); and 3) those with a large budget and many employees (32).

Research question 1 asked Are Pennsylvania nonprofit organizations familiar with the IRS Form 990 changes and the governance mechanisms available in the Sarbanes-Oxley Act? Of the 153 organizations participating in the survey, 28.1\% responded that they were very familiar with the Sarbanes-Oxley Act (Question 5) and 48.8\% responded that they were very familiar with the revised IRS Form 990 (Question 6).

There was an association with familiarity and organizational type. Only $14.5 \%$ of the Small / Few organizations indicated that they were very familiar with the Sarbanes-Oxley Act, while 65.6\% of the Large / Many organizations indicted that they were very familiar with the Sarbanes-Oxley Act (Question 5). These differences are statistically significant $X^{2}(2, \mathrm{~N}=153)=29.04, p=<0.0001$. A similar statistically significant trend by organization type $X^{2}(2$, $\mathrm{N}=153)=16.14, p=0.0003$ was also seen for familiarity with IRS Form 990 (Question 6).

Research question 2 asked Has the redesigned Form 990 caused Pennsylvania nonprofit organizations to adopt aspects of the Sarbanes-Oxley Act into their governance? Overall, $73.3 \%$ of the organizations indicated that they have a formal mechanism for assessing internal controls (Question 21), 62.5\% indicated that they have made changes in evaluation or documentation of internal controls (Question 24), 69.7\% indicated that their auditor issues a separate report on internal controls (Question 23), and 61.4\% indicated that having a formal mechanism for evaluating internal controls is important, very important, or extremely important (Question 22). In addition, overall, $44.1 \%$ of the organizations indicated that they have changed the structure of their audit committee (Question 11) and $40.8 \%$ have changed the structure of their Board of Directors (Question 15) since the revision of Form 990 or the enactment of Sarbanes-Oxley.

For questions 21 through 24 there were statistically significant trends evident with the proportion of organizations responding "yes" or "extremely important" being higher for the Large / Many organizations than for the Small / Few organizations. For question 21, the proportions responding "yes" were $96.8 \%$ versus $51.7 \%$, for the Large / Many organizations and Small / Few organizations, respectively $X^{2}(2, \mathrm{~N}=150)=25.96, p=<0.0001$; for question 22 the proportions responding "extremely important" or "very important" were 78.1 versus 46.8 , respectively $X^{2}(2, \mathrm{~N}=$ $153)=10.40, p=0.0055$; for question 23 the proportions responding "yes" were $93.6 \%$ versus $45.6 \%$, respectively $X^{2}(2, \mathrm{~N}=145)=27.25, p=<0.0001$; and for question 24 the proportions responding "yes" were $83.3 \%$ versus $37.9 \%$, respectively $X^{2}(2, \mathrm{~N}=144)=25.37, p=<0.0001$.

Research question 3 asked Are Pennsylvania nonprofit organizations audit committees and boards of directors established to ensure independence and knowledge of finance or financial auditing? Sixty-six percent of the organizations indicated that they had an audit committee (Question 7), for most of those with such a committee, that committee is independent. There was a trend with organizational type. The proportion of the of the Small / Few organization that had an audit committee was $41.9 \%$ compared to $78.0 \%$ of the Large / Few organizations and $90.6 \%$ of the Large / Many organizations $X^{2}(2, \mathrm{~N}=153)=28.42, p=<0.0001$. Among those organizations that indicated that they had an audit committee, $89.1 \%$ indicated that the members of their audit committee were independent (Question 9). One hundred percent of the Large / Many organization indicated this circumstance, compared to approximately $85 \%$ of all other companies. This difference was statistically significant (Exact test $\mathrm{p}$ - 


\section{Issues in Information Systems \\ Volume 15, Issue I, pp. 61-70, 2014}

value $=0.0497$ ). In addition, $95.0 \%$ of all organizations with an audit committee have at least one member with an accounting or finance background on their committee (Question 10), and $87.8 \%$ have at least one such experienced person on their Board of Directors (Question 14).

Research question 4 asked Are Pennsylvania nonprofit organizations familiar with the updated whistleblower provisions of the Sarbanes-Oxley Act? Overall, $76.7 \%$ of the organizations have provisions protecting whistleblowers (Question 16), and 51.7\% indicated that they have made changes to their whistleblower provisions since revisions to the Form 990 or the enactment of Sarbanes-Oxley (Question 18). Again, there was a statistically significant difference by type of organization for both of these aspects. In Small / Few organizations, 50.9\% have provisions protecting whistleblowers, while in Large / Few and Large / Many organizations the proportions were $91.5 \%$ and $96.9 \%$, respectively $X^{2}(2, \mathrm{~N}=150)=36.57, p=<0.0001$. Also, in the Small / Few organizations, $33.3 \%$ have made changes in their whistleblower provisions while in Large / Few and Large / Many the proportions were $65.5 \%$ and $62.5 \%$, respectively $X^{2}(2, \mathrm{~N}=147)=13.77, p=0.001$.

In addition to having provisions to protect whistleblowers, $44.1 \%$ of the organizations indicated that they have a hotline for employees to report unethical activity (Question 17). The proportion with such a mechanism was also associated with organizational type. In the Small / Few organizations, $24.6 \%$ have a hotline, while in Large / Few and Large / Many the proportions were $49.2 \%$ and $71.9 \%$, respectively $X^{2}(2, \mathrm{~N}=152)=20.05, p=<0.0001$.

Research question 5 asked Are Pennsylvania nonprofit organizations' top officers certifying financial reports and implementing a control structure conducive to preventing incidents of unethical abuses, malfeasance, and financial irregularities? Overall, $81.5 \%$ of the organizations indicated that they do require senior management to review, certify, and sign financial reports. The proportions indicating that they had such requirements ranged from $75.0 \%$ for Small / Few organizations to 87.5\% for Large / Many organizations (Question 19). These differences in proportions are not statistically significant from each other $X^{2}(2, \mathrm{~N}=151)=2.85, p=0.2402$. The proportion of organizations indicating that they hold senior management accountable for the accuracy of financial reports was $88.0 \%$ (Question 20). The proportions indicating this accountability ranged from $83.1 \%$ to $93.8 \%$. These differences were not statistically significant from each other Exact test $\mathrm{p}$-value $=0.3108$.

\section{CONCLUSIONS}

An extensive analysis of the study data resulted in a number of conclusions. These conclusions are based on the highest percentage answer for each survey question. Research question 1 asked, Are Pennsylvania nonprofit organizations familiar with the IRS Form 990 changes and the governance mechanisms available in the SarbanesOxley Act?

The researcher discovered that a surprisingly low number of organizations are very familiar with the Sarbanes-Oxley Act. Slightly more than quarter $(28.1 \%)$ of all organizations surveyed indicated that they were very familiar with the act. The Sarbanes-Oxley Act, a mandatory best-practices framework for publicly traded companies, is designed to enhance transparency and accountability to their stockholders. Nonprofit organizations, however, are not required to follow these guidelines.

Almost half (48.8\%) of all organizations surveyed indicated that they were very familiar with the IRS revisions to Form 990. The IRS Form 990 is designed to enhance the transparency and accountability of nonprofit organizations to their donors.

The statistical data seem to indicate that nonprofit organizations are not concerned with the governance mechanisms outlined in the Sarbanes-Oxley Act. These organizations are, however, facing the same best practices framework as their for-profit counterparts, although they are doing it under different regulations. Independent Sector, a leading nonprofit trade organization states, "The revised [IRS] Form 990 is much more than a financial document - it's the primary source of information about [an organization's] governance, operations, and programs available to government regulators, the press, and the public (Independent Sector, 2010).

Research question 2 asked, Has the redesigned Form 990 caused Pennsylvania nonprofit organizations to adopt aspects of the Sarbanes-Oxley Act into their governance? 


\section{Issues in Information Systems \\ Volume 15, Issue I, pp. 61-70, 2014}

The Sarbanes-Oxley Act requires an organization to have formal mechanisms for the assessment and evaluation or documentation of their internal controls. The act also requires an organization's auditors to issue separate reports on these internal control structures. A little less than half (44.1\%) of survey respondents had changed the structure of their audit committee since the revision of Form 990, whereas $(40.8 \%)$ of survey respondents had changed the structure of their boards of directors.

A majority of survey respondents (73.3\%) indicated that they had formal mechanisms for assessing their internal controls. Over half of the survey respondents indicated that they: 1) had a formal mechanism (61.4\%) for evaluation of their internal controls; 2) had their auditor issue separate reports (69.7\%) on their internal controls; and 3) made changes in how they evaluated and documented (62.5\%) their internal controls.

According to the statistical data, the trends found were statistically significant, with the proportion of organizations responding "yes" or "extremely important" being higher for the Large / Many organizations than for the Small / Few organizations.

Research question 3 asked, Are Pennsylvania nonprofit organizations audit committees and boards of directors established to ensure independence and knowledge of finance or financial auditing?

More than half $(66.0 \%)$ of survey respondents indicated that they had an audit committee; among the respondents that indicated they had an audit committee, the majority (87.8\%) of these respondents indicated that these committees were independent. One hundred percent of the Large / Many organizations indicated this circumstance, compared to approximately $85 \%$ of all other organization types. In addition, almost all $(95.0 \%)$ of respondent organizations with an audit committee have at least one member with an accounting or finance background on their committee, and a majority $(87.8 \%)$ have at least one such experienced person on their board of directors.

Research question 4 asked, Are Pennsylvania nonprofit organizations familiar with the updated whistleblower provisions of the Sarbanes-Oxley Act?

The majority $(76.7 \%)$ of survey respondents indicated that they had provisions protecting whistleblowers. A little over half $(51.7 \%)$ of surveyed respondents indicated that they had made changes to their whistleblower provisions since either the revisions to IRS Form 990 or the enactment of the Sarbanes-Oxley Act. Among the organizations that indicated they were familiar with these updated provisions to the whistleblower protections, the Small / Few organization type came in last, at $50.9 \%$ for familiarity, while the Large / Few organization type came in at $91.5 \%$, and the Large / Many organization type came in at $96.9 \%$.

Interestingly, slightly less than quarter $(23.3 \%)$ of survey respondents had no whistleblower protection plan. This raises some concerns about employee rights at smaller organizations as well as possible liability issues. It should come as no surprise because the whistleblower protection laws were revised when the Sarbanes-Oxley Act was signed into law. The real concern, surrounding this finding (because it is so low) was raised when examining survey question 5, How familiar are you with the Sarbanes-Oxley Act of 2002? Slightly more than quarter (28.1\%) of all organizations surveyed indicated in their answers to that question that they were very familiar with the SarbanesOxley Act. These percentages appear to be similar and are both reflective of answers received from those at the Small/Few organizations.

Research question 5 asked, Are Pennsylvania nonprofit organizations' top officers certifying financial reports and implementing a control structure conducive to preventing incidents of unethical abuses, malfeasance, and financial irregularities?

The majority (81.5\%) of survey respondents indicated that they do require senior management to review, certify, and sign financial reports. The proportions indicating that they had such requirements ranged from $75.0 \%$ for Small / Few, to $87.5 \%$ for Large / Many organization types. The majority (88.0\%) of survey respondents indicated that they hold senior management accountable for the accuracy of financial reports.

For smaller organizations the costs associated with the compliance to these revised regulations has increased their 


\section{Issues in Information Systems}

Volume 15, Issue I, pp. 61-70, 2014

burden and decreased their benefit to the community by means of how much of their budgets now must be spent on compliance. The IRS, realizing these burdens, has set reporting requirements thresholds; organizations with gross receipts less than $\$ 25,000$ are required to report annually using Form 990-N e-Postcard designed to ease this reporting burden. Those organizations with gross receipts greater than $\$ 25,000$, however, are required to report annually using Form 990.

\section{Recommendations}

There is no denying that transparency and accountability are needed in the nonprofit sector. Leadership, ethical conduct, and accountability must come from the top and disseminate to all facets of an organization. Holding an organizations top officer accountable for the veracity of his or her organization's financial statements is the first step in this process of transparency and accountability.

The revisions to IRS Form 990 are a step in the right direction for holding organizational leaders accountable for their misconduct. Form 990 mandates changes in nonprofit governance by ensuring that financial reports are certified and that policies and financial controls are in place to prevent incidents of fraud and misuse of funds. While there is no denying that these types of controls are conducive to good organizational governance, no one has considered the financial impact to organizations whose gross receipts are above $\$ 25,000$. Once an organization surpasses the $\$ 25,000$ threshold, it can no longer file Form 990-N.

Dramatically increasing the reporting burden on organizations, the revised Form 990 increases the need for audited financial reports and controls. The increased reporting burden of Form 990 can increase administrative costs in the same way Sarbanes-Oxley increased the administrative costs of organizations attempting to comply with section 404. Any increase in administrative costs will negatively impact smaller nonprofit organizations.

The researcher recommends that the IRS take the following three actions to minimize the impact of these reporting burdens that unnecessarily and unfairly impact small nonprofit organizations whose gross receipts are above $\$ 25,000$. First, implement electronic filing for all organizations; there is an unfair reporting burden placed upon those organizations whose gross receipts is less than $\$ 250,000$. Second, eliminate all fees associated with the filing Form 990 for all organizations across the board. Finally, revise the filing thresholds for organizations; do not burden organizations with gross receipts less than $\$ 5,000,000$ with mandated audits. The goal of the revised Form 990 was transparency and accountability to the public; however, there is no reason to saddle nonprofit organizations with onerous burdensome regulations.

A German proverb states, "Charity sees the need, not the cause." The state and federal government should be looking for ways to eliminate the burdens of nonprofit organizations, not adding to them. By taking the above recommendations, the IRS can benefit the public good by seeking transparency and accountability and can help to decrease the operating costs associated by these new reporting requirements.

\section{REFERENCES}

1. Bakale, A. (2009). Revised Form 990: The Evolution of Governance and the Nonprofit World. The Tax Adviser, 40(8), 507-510.

2. Brown, W., \& Nasuti, F. (2005). Sarbanes-Oxley and Enterprise Security: It Governance - What It Takes to Get the Job Done. Information Systems Security, 14(5), 15.

3. Caplan, R. (2009). Irs Releases Redesigned Form 990. The Tax Adviser, 40(4), 254-255.

4. D'Aquila, J. (2004). Tallying the Cost of the Sarbanes-Oxley Act. The CPA Journal, 74(11), 6-9.

5. Fremont-Smith, M. R., \& Kosaras, A. (2003). Wrongdoing by Officers and Directors of Charities: A Survey of Press Reports 1995-2002. SSRN eLibrary, 48. doi: 10.2139/ssrn.451240

6. Gibelman, M., \& Gelman, S. (2000, July 7, 2000). Very Public Scandals: An Analysis of How and Why Nongovernmental Organizations Get in Trouble. Paper presented at the International Society for Third-Sector Research (ISTR), Fourth International Conference, Dublin, Ierland.

7. Gilkeson, N. (2007). For-Profit Scandal in the Nonprofit World: Should States Force Sarbanes-Oxley Provisions onto Nonprofit Corporations? Georgetown Law Journal, 95(3), 831.

8. Grindler, G., \& Jones, J. (2004). Please Step Away from the Shredder and the "Delete" Key: $\S 802$ and 1102 of 
the Sarbanes-Oxley Act. . The American Criminal Law Review; , 41(1), 67-91.

9. Halloran, P., \& Higgins, G. (2008). The New Form 990. The Bottom Line, 23(7), 22-24.

10. Hempel, J., \& Borrus, A. (2004). Now the Nonprofits Need Cleaning up; Cozy Boardrooms at Colleges and Charities Face Increasing Government Scrutiny. Business Week, June 21, 107.

11. Isaza, J. (2005). Know When to Hold 'Em, When to Destroy 'Em. Information Management Journal, 39(2), 3944.

12. Iyer, V., \& Watkins, A. (2008). Adoption of Sarbanes-Oxley Measures by Nonprofit Organizations: An Empirical Study. Accounting Horizons, 22(3), 255.

13. Mulligan, L. (2007). What's Good for the Goose Is Not Good for the Gander: Sarbanes-Oxley Style Nonprofit Reforms. Michigan Law Review, 105(8), 1981.

14. O'Hare, P. (2002). Sarbanes-Oxley Raises a Red Flag for Not-for-Profits. Healthcare Financial Management, $56(10), 42-44$.

15. Orlikoff, J., \& Totten, M. (2004). Applying for-Profit Governance Reforms. Healthcare Executive, 19(3), 52, 54.

16. Pomeroy, A. (2006). Sarbanes-Oxley Costs Affect Smaller Companies the Most. HRMagazine, 51(8), 14-16.

17. Public Company Accounting Reform and Investor Protection Act, 116, Pub. L. No. 107-204, 745 Stat. 66 (2002 July 30, 2002).

18. Schneider, G., \& Bruton, C. (2007). Sarbanes-Oxley Compliance: New Oppertunties for Information Technology Professionals. Academy of Information and Management Sciences Journal, 10(2), 79-89.

19. Sector, i. (2009). Accountability. Retrieved November 13, 2009, from http://www.independentsector.org/accountability old?s=accountability

20. Sector, I. (2010). $\quad$ Irs Form 990. $\quad$ Retrieved $\quad$ November $\quad 9$, 2010, from http://www.independentsector.org/form 990

21. Silk, T., \& Fei, R. (2005). California's Nonprofit Integrity Act of 2004 (Sb 1262). The International Journal for Not-for-Profit Law, 7(2).

22. Smoker, K., \& Mammano, K. (2009). The Revision of Federal Form 990: A Move toward Sox-Like Reform in the Nonprofit Sector. The CPA Journal, 79(7), 52-55.

23. Steuer, J. (2007). Surprise! Sarbanes-Oxley (at Least Some of It) Is Law for Nonprofits. Pennsylvania CPA Journal, 78(1), 22-23.

24. Wyllie, B. (2009). The Redesigned Form 990. Journal of Accountancy, 207(3), 72-78. 